\title{
IMMUNOHISTOCHEMICAL STUDY OF THE ULTIMOBRANCHIAL REMNANTS IN THE CAMEL
}

\author{
SAEED Y. AL-RAMADAN \\ Anatomy Department, College of Veterinary Medicine and Animal Resources, King Faisal University, \\ Al-Ahsa, Saudi Arabia. \\ Corresponding Author (salramadan@kfu.edu.sa)
}

\section{ABSTRACT}

Received at: $26 / 3 / 2013$

Accepted: 18/4/2013

\begin{abstract}
The ultimobranchial remnants were investigated in the thyroid gland of the adult camel. The vestiges of this structure were appeared in various forms and shapes. The most common shapes were large follicles with various arts, distended cysts, solid cell nests and small irregular follicles. The lining epithelium of those follicles and cysts was found to be variable. The solid cell nests were represented by masses of basophilic epithelial cells surrounded with connective tissue. Immunohistochemical staining of the ultimobranchial remnants against calcitonin was performed and different intensities were recorded. The most intense stain was detected at the solid cell nests. Our immunohistochemical findings confirm that the remnants of the ultimobranchial body is also present in the thyroid glands of adult camel.
\end{abstract}

Key words: Ultimobranchial, Camel, Structure, Immunohistochemistry.

\section{INTRODUCTION}

The ultimobranchial body (UBB) is the origin of calcitonin cells ( $\mathrm{C}$ cells) of the thyroid gland. In mammals except monotremes, the ultimobranchial body will fuse with the thyroid gland premordium forming paired glandular tissue, the thyroid gland, with two types of hormone producing cells, the follicular and parafollicular cells. In lower vertebrates including birds and fish, the primordia of the ultimobranchial body and thyroid premordium remain separate to form ultimobranchial and thyroid glands (Kameda, 1984; 1993; Alt et al., 2006; Fagman and Nilsson 2010). Interestingly, in the monotremes, which forms the most primitive subclass of mammalians, the ultimobranchial body remains as separate organ ventrolateral to the commencement of the trachea the thorax (Haynes, 1999). In higher mammalian subclasses, however, although both organs merged together to form thyroid gland but remnants of the ultimobranchial body have been observed in many species postnatally including human. In cattle, for instance, the ultimobranchial body and the pathological conditions that might developed from it have been described early in several publications (Krook, 1969; Young et al., 1971; Ljungberg and Nilsson, 1985; Harmon and Kelley, 2001). The ultimobranchial remnants were also thoroughly investigated in other domestic mammals like horse (Ueki et al., 2004), dog (Zarrin, 1977), sheep (Jordan et al., 1973), goat (Roy et al.,
1978); Buffalo (Sayed et al., 2004); donkey (Sayed et al., 2004) and cat (Titlbach et al., 1987). Adding to that accumulating reports that is focuses on the UBT researches of mouse (Ozaki et al., 2011; Kusakabe et al., 2006); wild rodents (Sawicki and Zabel., 1999); rat (Nishiyama et al., 1996); Bison (Sawicki and Zabel., 1997) and human (Fagman and Nilsson., 2010; Khan and Nose 2010). In addition to regular C cells that scattered around the follicles, the vestiges of UBB could be observed in young and adult animals with different forms and shapes. Cysts with various epithelial linings, solid cell nests (SCNs), intra-and parafollicular cell clusters are among the shapes of the UBB remnants (Janzer et al., 1979).

In our laboratory, we have been using camel as a model in our studies of the thyroid glands. While examining the structure of thyroid glands we were frequently encountered with nodular structures embedded within the thyroid tissue. From histological examinations, we found those structures might be representing the ruminants of UBB (Fath-Elbab et al., 2000). As far as we can tell from the available international literatures that have been the first time to report the presence of UBB in adult camel. Later, Mubarak and Sayed (2004) have published an abstract describing the ultrastructure of the $\mathrm{C}$ cells in camel where they noticed that the SCNs were highly populated with $\mathrm{C}$ cells. Here we are reporting our findings on the UBB of the camel using the immunohistochemical (IHC) demonstrating 
calcitonin-like activity within these structures. Our result might provide an insight into the remnants of $\mathrm{UBB}$ and addresses the origin of $\mathrm{C}$ cells in the this animal species.

\section{MATERIALS and METHODS}

\section{Animals and tissue collection}

Samples were collected from 6 apparently healthy male and female dromedary camels (Camelus dromedarius). Short time after slaughtering at Alomran Slaughter House, Al-Ahsa, Eastern Province, Saudi Arabia, the thyroid gland were examined and only those free from any gross pathological changes during postmortem examination were selected. Both gland lobes were collected and immediately fixed in $4 \%$ paraformaldehyde in PBS (pH 7.3). After 48 hours each lobe was serially sliced into several $\sim 5 \mathrm{~mm}$ thick slices and embedded in Paraplast Tissue embedding Media (Leica Microsystems, St. Louis, MO).

\section{Conventional Histological staining}

Standard hematoxylin and eosin (H\&E) protocol according to Bancroft and Cook (1994) were used to investigate general histological structures of the thyroid gland and only those blocks showed the presence of the UBB remnants were selected for the immunohistochemical examinations.

\section{Immunohistochemistry}

The expression of calcitonin hormone was evaluated in paraformaldehyde- fixed, paraffin-embedded, UTB cross-sections $(4 \mu \mathrm{m})$ using procedures described by manufacturer. Calcitonin producing cells were detected with primary anti-calcitonin antibodies (Polyclonal rabbit anti-human calcitonin, 1:100 dilution; Catalog No. A0576; Dako,Glostrup, Denmark). Briefly, sections were dewaxed, rehydrated and incubated overnight with primary antibodies at $4{ }^{\circ} \mathrm{C}$, while the rest of incubation were performed at room temperature. After several washings, sections were then incubated with secondary biotinylated antibodies for $30-60 \mathrm{~min}$. After washing with PBS, the sections were incubated with streptavidin-HRP conjugate (HSS-HRP) for 30 min. and finally washed. Visualization was achieved by immersing sections in freshly prepared AEC chromogen solution until desired stain intensity developed. These sections were evaluated using a light microscope at magnifications of $4 \times, 10 \times, 40 \times$, and $100 \times$. Histological images were obtained with Leica DM6000-B microscope and Leica DEC-420 digital camera (Leica Microsystems, Germany). For negative controls, primary antibodies were substituted with PBS, while the rest of procedures were maintained. Controls were carried out on sections adjacent to those used in normal immunostaining protocol.

The labeling intensity of cells was scored on a subjective scale of: Negative; (-) Weak; (+) Moderate; (++) Strong; (+++) and very strong (++++).

\section{RESULTS}

Various shapes and forms of the UBB remnants have been observed. The most common shapes were large follicles with various arts, distended cysts, SCNs and small irregular follicles (Fig.1). Most of theseUBB remnants were observed under the capsule or near the surface of the gland within the connective tissue trabeculae. However, occasionally, some UBB remnants were found deeply embedded within the thyroid tissue. All of the hollow structures examined contain no colloid or some time scattered debris could be observed.

The lumen of the large follicles showed irregular branched folds that are lined by simple cuboidal, simple columnar, stratified cuboidal or pseudostratified columnar epithelia (Fig. 1, A\& Fig. 2, A). A distended cysts lined with simple squamous and/or simple cuboidal and/or stratified squamous epithelium were also among the lining epithelium of this UBB remnants of (Fig. 1, B\& Fig. 2, C). Our data also showed that there were clusters of SCNs which are usually observed to be scattered around the UBB cysts and follicles (Fig.1,C). Those nests represented by masses of epithelial cells surrounded with connective tissue. The cells of these nests showed variable staining intensities. However, the majority are faintly basophilic (Fig. 1, C\& Fig. 2, E). The small follicles are of variable shapes and found with the same vicinity of the other UB remnants enclosed within the same connective tissue as well. They are also lined with variable epithelial lining (Fig. 1, D\& Fig. 2, G).

Immunohistochemical staining of the epithelium linings with anti-calcitonin showed moderate $(++)$ at the large follicles (Fig.2, B). On the other hand, epithelial lining of the distended follicles showed stronger $(+++)$ affinity to the calcitonin antibodies (Fig.2, D). The highest immunoreactivity $(++++)$ to calcitonin was detected at the SCNs (Fig. 2, F). While the epithelial lining of the small irregular follicles showed moderate staining toward calcitonin antibodies (Fig. 2, H). 

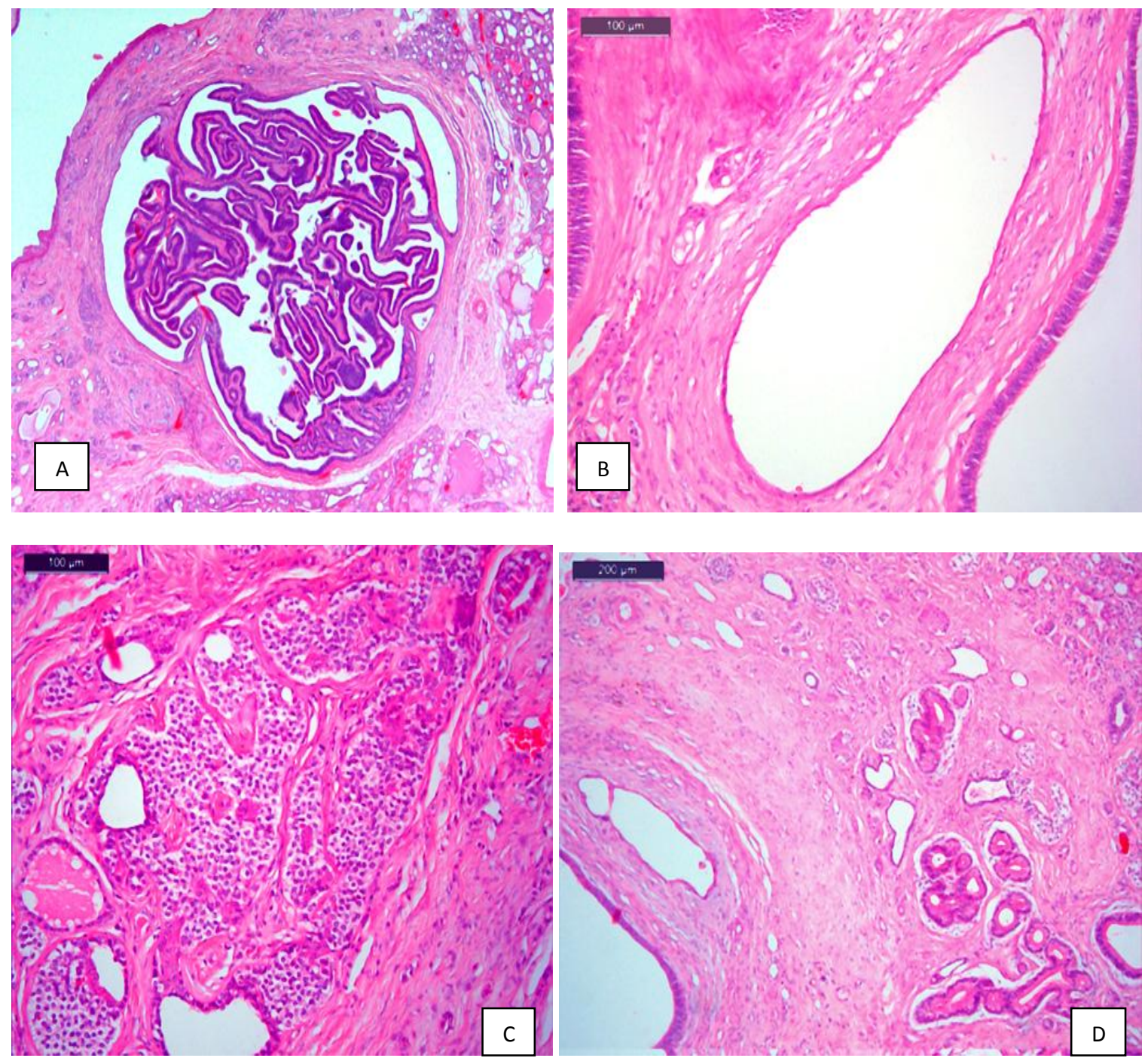

Fig.1: Different forms of the ultimobranchial remnants within the thyroid glands adult camels showing: (A) Large follicles with different arts where the wall of these follicles thrown into folds of different levels. (B) Distended cyst, without any colloid. (C) Solid cell nests, with masses of basophilic epithelial cells surrounded with connective tissue. (D) Small follicles, found within the connective tissue of the UBB, different architecture of the regular thyroid follicles. (H\&E stain) 


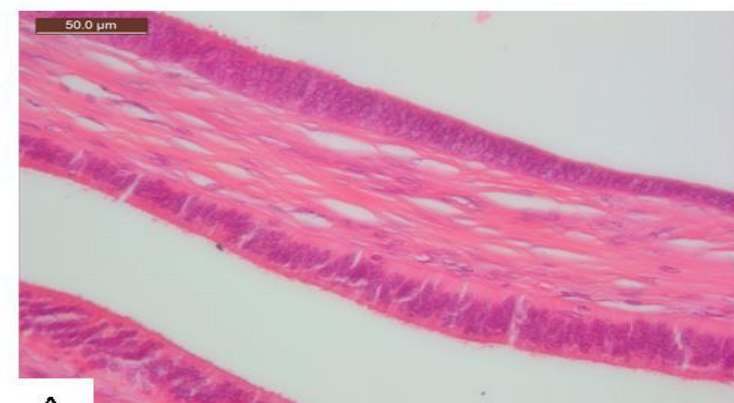

A
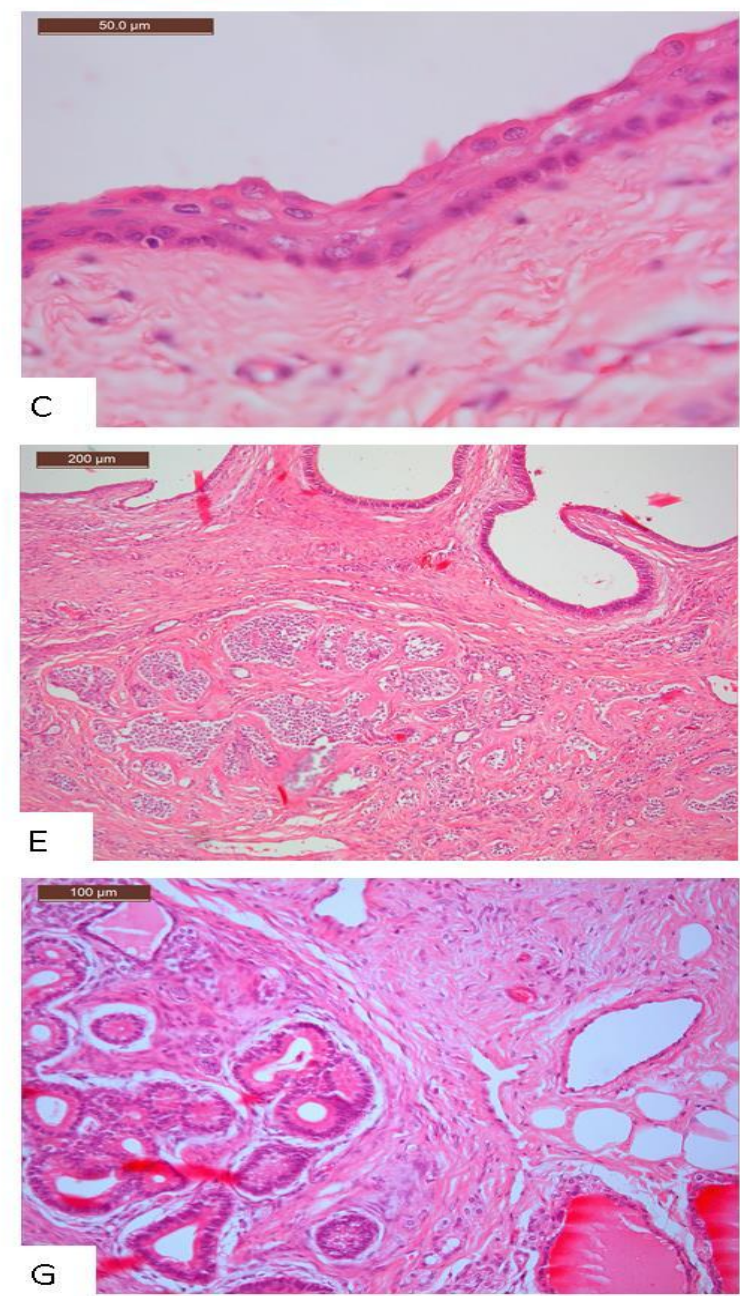
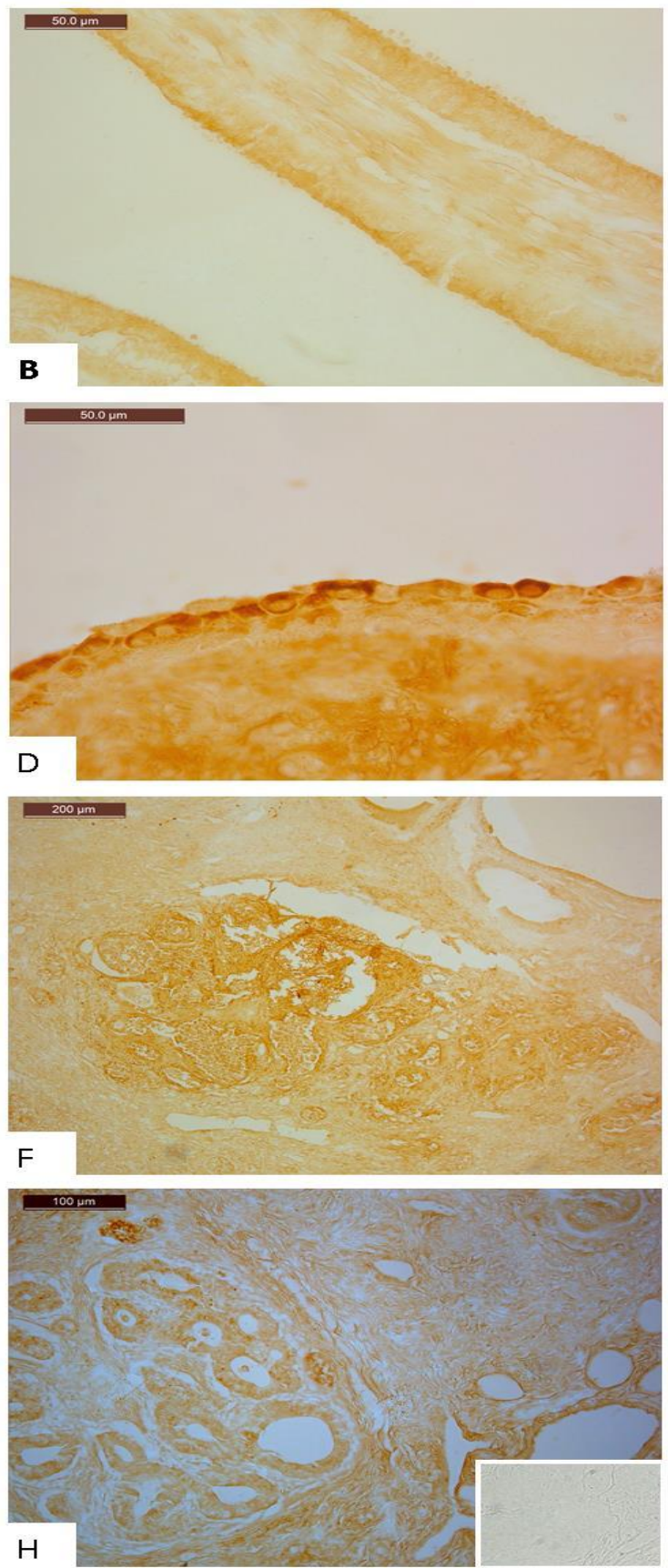

Figure 2: Different forms of the UBB stained with H\&E,left column, and their similar sections immunostained with calcitonin antibodies, right column. showing: (A) Stratified columnar epithelial lining of the large follicles. (B) Immunostaining for the epithelial lining of the large follicle. (C) Stratified squamous epithelium lining of the distended follicle. (D) positive immunoreactivity at the upper layer of the squamous epithelium in the distended follicles. (E) Solid cell nests. (F) intense immunoreactivity in the SCNs. $(\mathrm{G})$ group of small irregular follicles. $(\mathrm{H})$ moderate immunestaining in the epithelial lining of these follicles. The insertion in bottom of figure $(\mathrm{H})$ represent the negative control where the primary antibody is replaced with antibody diluents. 


\section{DISCUSSION}

The thyroid gland of many mammals formed of two diverse cell types (thyroid follicular cell, and the parafollicular cell, C cells or Calcitonin cells), responsible for the dual endocrine function of the gland. They originate from two different embryological structures: the thyroid anlage is the site of origin of the thyroid follicular cell whereas the ultimobranchial bodies are the source of $\mathrm{C}$ cells. The thyroid anlage is an area enclosing a small group of endodermal cells, and it is located on the midline of the embryonic mouth cavity in its posterior part. The ultimobranchial bodies are pair of transient embryonic structures derived from the fourth pharyngeal pouch and located symmetrically on the sides of the developing neck. The $\mathrm{C}$ cell precursors migrate from the neural crest bilaterally to the fourth pharyngeal pouches and become localized in the ultimobranchial bodies. The cells of the thyroid anlage and the ultimobranchial bodies migrate from their respective sites of origin and ultimately merge in the definitive thyroid gland. Interestingly, in some animals the ultimobranchial structures remain distinct from the rest of the thyroid gland (Reviewed in De Felice and Di Lauro, 2004).

Observation made in the current study, confirm that the remnants of the ultimobranchial body is also present in the thyroid glands of the camel. The conventional microscopic findings detected various shapes and forms of the UBB under the capsule of the thyroid glands or within the connective tissue trabeculae. The most common shapes spotted were large follicles with various arts, distended cysts, SCNs and small irregular follicles. Similar findings were also observed in thyroid glands of young and adult animals (Janzer et al., 1979). Our study also shows that the UBB cysts and the follicles are lined with various epithelial linings. This variations in the epithelial lining of the UBB follicles have been reported in different studies. Early at 1945, Van Dyke has described various forms of UB cysts lined with variable types of epithelium in the thyroid gland of sheep. Later, a similar observation has been recorded in the cattle (Ljungberg and Nilsson, 1985); Bison (Sawicki and Zabel, 1997), mouse (Kusakabe et al., 2006) and human (Janzer et al., 1979).

Another form of UBB remnants that we reported in the current study is the solid cell nests.These SCNs are formed of single or multiple foci of clusters of cells (Cameselle-Teijeiro et al., 2005). In human, SCN can be seen in up to $60 \%$ of thyroid glands in the mid portions of the lateral lobes. They were represented by solid irregular masses of epithelial cells measuring about $1 \mathrm{~mm}$ or less in maximum diameter and may be solitary or multiple, unilateral or bilateral. Variable shapes of the cells within the nests were also recorded (Khan and Nose 2010). Different cellular elements in various proportions and of small follicles within a delicate, highly vascular stroma have been reported in the dog (Leblanc et al., 1990) and cattle (Harmon and Kelley 2001).

Interestingly, our immunohistochemical staining showed that these all the aforementioned structures were positive to calcitonin, a finding which is also reported in human and other species (Khan and Nose 2010; Leblanc et al., 1990; Sawicki and Zabel, 1999, 1997). This observation in camel and other species, gives support to the theory of that these structure are derivatives of the ultimobranchial body and might represent the source for the $\mathrm{C}$ cell during adulthood life of the animal.

In conclusion, the importance of reporting about the presence and studying the structural features of the UBB remnants lies behind the relation between these structures and the potential of developing some thyroid tumors. For instance, $10 \%$ male and 20\% female rats were found to have foci of C-cell hyperplasia (Rao-Rupanagudi et al., 1992). In another study in cattle, Harmon and Kelley (2001) could detect 7 out of 8 studied thyroid tumors were of ultimobranchial origin. We came across many grossly abnormal thyroid glands that we exclude from our study. Those enlarged thyroid glands might represent different types of tumor of ultimobranchial origin. Therefore, epidemiological and histopatholigical studies about the prevalence of the thyroid tumors and their origin have to be done in camel.

\section{Acknowledgments:}

The author is grateful to his colleagues from Anatomy Departments, King Faisal University, in particular Prof. Doctor Abdelhadi M. Ali, forhelpful discussion and support. People in Alomran Slaughter House, Al-Ahsa, SaudiArbia are highly acknowledged for providing us with samples.

\section{REFERENCES}

Alt, B.; Reibe, S.; Feitosa, N.M.; Elsalini, O.; Wendl, T. and Rohr, K.B. (2006): Analysis of origin and growth of the thyroid gland in zebrafish. Developmental Dynamics. 235: 1872-1883.

Bancroft, JD. and Cook, HC. (1994): Manual of histological techniques and their diagnostic application, Churchill Livingstone, Edinburgh, UK.

Cameselle-Teijeiro, J.; Preto, A.; Soares, P. and Sobrinho-Simões, M. (2005): A stem cell role for thyroid solid cell nests. Human Pathology, 36: 590-591. 
De Felice, M. and Di Lauro, R. (2004): Thyroid development and its disorders: genetics and molecular mechanisms. Endocrine Reviews 25: 722-46.

Fagman, H. and Nilsson, M. (2010): Morphogenesis of the thyroid gland. Molecular and Cellular Endocrinology 323: 35-54.

Fath El-bab, M.R.; Ali, A.M.; Ahmed, K.A. and AIRamadan, S.Y. (2001): Micromorphological studies on the thyrocalcitonin cells in the thyroid gland of the camel. Sixth Annual Conference for Animal Production Under arid Conditions, November 11-13, 2001, Al-Ain, United Arab Emirates.

Harmon, B.G. and Kelley, L.C. (2001): Immunohistochemistry of Ultimobranchial Thyroid Carcinomas in Seven Slaughtered Cows and One Bull. Journal of Veterinary Diagnostic Investigation 13: 101-105.

Haynes, J.I. (1999): Parathyroids and ultimobranchial bodies in monotremes. The Anatomical Record 254: 269-280.

Janzer, R.C.; Weber, E. and Hedinger, C. (1979): The relation between solid cell nests and $\mathrm{C}$ cells of the thyroid gland: an immunohistochemical and morphometric investigation. Cell and Tissue Research 197: 295-312.

Jordan, R.K.; McFarlane, B. and Scothorne, R.J. (1973): An electron microscopic study of the histogenesis of the ultimobranchial body and of the C-cell system in the sheep. Journal of Anatomy 114: 115-136.

Kameda, $\quad Y$. (1984): Ontogeny of chicken ultimobranchial glands studied by an immunoperoxidase method using calcitonin, somatostatin and 19S-thyroglobulin antisera. Anatomy and Embryology 170: 139-144.

Kameda, Y. (1993): Anatomy and Embryology of the chicken ultimobranchial glands, with special reference to innervation of $\mathrm{C}$ cells. Anatomy and Embryology 188: 561-570

Khan, A. and Nose, V. (2010): Endocrine Pathology: Differential Diagnosis and Molecular Advances. $2^{\text {nd }}$ Ed. (R. V. Lloyd, Ed.). Springer. New York.

Krook, L. (1969): Dietary Calcium, Ultimobranchial Tumors and Osteopetrosis in the Bull. The American Journal of Clinical Nutrition. 22: 115-118.

Kusakabe, T.; Hoshi, N. and Kimura, S. (2006): Origin of the ultimobranchial body cyst: T/ebp/Nkx2.1 expression is required for development and fusion of the ultimobranchial body to the thyroid. Developmental Dynamics 235: 1300-1309.

Leblanc, B.; Paulus, G.; Andreu, M. and Bonnet, M.C. (1990): Immunocytochemistry of
Thyroid C-Cell Complexes in Dogs. Veterinary Pathology 27: 445-452.

Ljungberg, O. and Nilsson, P.O. (1985): Hyperplastic and neoplastic changes in ultimobranchial remnants and in parafollicular (C) cells in bulls: a histologic and immunohistochemical study. Veterinary Pathology 22: 95-103.

Mubarak, $W$. and Sayed, $R$. (2004):Ultramicroscopical study on thyrocalcitonin cells in the camel (Camelusdromedarius). The 25th Congress of the European Association of Veterinary Anatomists (EAVA), Oslo, 28-31 July 2004.

Nishiyama, I.; Ogiso, M.; Oota, T.; Kimura, T. and Seki, T. (1996): Developmental change in expression of highly polysialylated neural cell adhesion molecule in C-cells in rat thyroid gland. Anatomy and Embryology 194: 419426.

Ozaki, T.; Nagashima, K.; Kusakabe, T.; Kakudo, K. and Kimura, S. (2011): Development of thyroid gland and ultimobranchial body cyst is independent of p63. Laboratory investigation 91: 138-46.

Rao-Rupanagudi, S.; Heywood, R. and Gopinath, C. (1992): Age-related changes in thyroid structure and function in sprague-dawley rats. Veterinary Pathology 29: 278-287.

Roy, K.S.; Saigal, R.P.; Nanda, B.S. and Nagpal, S.K. (1978): Gross, histomorphological and histochemical changes in thyroid gland of goat with age. II. Occurrence of ultimobranchial follicles. AnatomischerAnzeiger 143: 72-85.

Sawicki, B. and Zabel, M. (1997): Immunocytochemical study of parafollicular cells of the thyroid and ultimobranchial remnants of the European bison. ActaHistochemica 99: 223-230.

Sawicki, B. and Zabel, M. (1999): Immunocytochemical study of parafollicular (C) cells of the thyroid in some wild rodents. Annals of Anatomy 181: 173-180.

Sayed, R.; Aly, K.H. and Mubarak, W. (2004): Surface ultrastructure of ultimobranchial remnants in the thyroid gland of buffalo (Bosbubalis). The 25th Congress of the European Association of Veterinary Anatomists (EAVA), Oslo, 28-31 July 2004.

Sayed, R.; Mubarak, W. and Saleh, A.M. (2004): Ultimobranchial epithelium in the thyroid gland of donkey (Equusasinus). The $25^{\text {th }}$ Congress of the European Association of Veterinary Anatomists (EAVA), Oslo, 28-31 July 2004.

Titlbach, M.; Velick, J. and Lhotovfi, H. (1987): Prenatal development of the cat thyroid: immunohistochemical demonstration of calcitonin in the " $\mathrm{C}$ " cells. Anatomy and Embryology 177: 51-54. 
Ueki, H.; Kowatari, Y.; Oyamada, T.; Oikawa, M. and Yoshikawa, H. (2004): Non-functional Ccell adenoma in aged horses. Journal of Comparative Pathology 131: 157-165.

Van Dyke, J.H. (1945): Behavior of ultimobranchial tissue in the postnatal thyroid gland: Epithelial cysts, their relation to thyroid parenchyma and to "new-growths" in the thyroid gland of young sheep. American Journal of Anatomy 76: 201-251.
Young, D.M.; Capen, C.C. and Black, H.E. (1971): Calcitonin Activity in Ultimobranchial Neoplasms from Bulls. Veterinary Pathology 8: 19-27.

Zarrin, K. (1977): Naturally occurringparafollicular cell carcinoma of the thyroid in dogs. A histological and ultrastructural study. Veterinary Pathology14: 556-566.

\title{
دراسة هستولوجية مناعية لبقايا الأجسام الخيشومية النهائية في الجمل
}

\author{
سعيد ياسبن الرمضان \\ تمت در اسة بقايا الأجسام الخيشومية النهائية في الغدة الدرقية للإبل البالغة . وظهر أثار هذا التركيب في اشكال متعددة . كانت الأشكال \\ الأكثر شيو عا حويصلات كبيرة ذات نقوش مختلفة، و أكياس منتفخة، وكتل خلوية صلبة وبصبلات غير انتظامية الصغيرة ـوقد وجد \\ اختلافا في البطانة الطلائية لهذه الحويصلات و الأكياس. أما الكنل الخلوية فقد تمثلت بخلايا طلائية قاعدية محاطة بانسجة ضامة ـ كما \\ تم صبغ هذه البقايا الخيشومية النهائية بواسطة الكيمياء الهستولوجية المناعية لهرمون الكالسيتونين ـ حيث تم تسجيل أعلى درجة من \\ الصباغة في الكتل الخلوية الصلبة. وتعتبر هذه النتيجة للصباغة دليل على ان هذه الاشكال تعتبر بقايا للأجسام الخيشومية النهائية في \\ الغدة الدرقية للابل البالغة .
}

